DOI 10.37882/2223-2982.2020.08.30

\title{
РАЗВИТИЕ РЕАКТИВНЫХ СИСТЕМ ЗАЛПОВОГО ОГНЯ И ИХ ПРИМЕНЕНИЕ ВООРУЖЕННЫМИ СИЛАМИ В ПЕРИОД МИРОВЫХ ВОЙН НА ВОЕННО-МОРСКИХ СУДАХ
}

\section{DEVELOPMENT OF REACTIVE SELF- FIRING SYSTEMS AND THEIR USE BY ARMED FORCES DURING THE WORLD WARS ON NAVAL SHIPS}

\section{S. Sytnikov}

Summary: The article discusses the issues of the historical and military development of multiple launch rocket systems on naval vessels during the world wars. In the course of the study, the author's approach to ranking the results of the evolution of means of warfare and methods of warfare was proposed, which made it possible to establish that the development of modern missiles originates in the wars of the third generation. Special attention is paid to the development of anti-aircraft systems in the Navy in the USSR, Germany, USA, Great Britain. The types and characteristics of missile systems used on warships are considered.

Keywords: ship, anti-aircraft missiles, war, Katyusha, weapons.
$\mathrm{H}$ а сегодняшний день армии достаточно большого количества стран мира имеют на вооружении реактивные системы залпового огня, которые составляют значительную часть их огневой мощи. Но, прежде чем стать одним из основных современных вооружений, ракетные комплексы прошли долгий и довольно непростой путь развития.

В начале тридцатых годов прошлого века, готовясь к новой войне, большинство государств Европы, в первую очередь, Германия и СССР, а также США развернули новый виток гонки вооружений. Разработка оружия после первой мировой войны была ограничена Версальским договором. Но, регламентируя численность, калибры, боекомплект и характеристики артиллерийского вооружения, договор абсолютно не ограничивал разработку ракетного оружия. Отдельный акцент необходимо сделать, на том, что развитие реактивных систем залпового огня значительным образом повлияло на эволюцию военно-морского флота, изменило классические военноморские доктрины и сыграло важную роль на стратегическом уровне в двух мировых войнах.

При этом, несмотря на значительное количество литературы, посвященной разработке как самих реактивных систем залпового огня, так и военных конфликтов с их использованием, комплексного военно-историческо-

\author{
Ситников Сергей Павлович \\ Соискатель, преподаватель, Михайловская военная \\ артиллерийская академия, г. Санкт-Петербург \\ odecca74@mail.ru
}

Аннотация: В статье рассматриваются вопросы историко-военного развития реактивных систем залпового огня на военно-морских судах в период мировых войн. В процессе исследования предложен авторский подход к ранжированию результатов эволюции средств вооруженной борьбы и способов ведения боевых действий, который позволил установить, что развитие современных ракет берет свое начало в войнах третьего поколения. Отдельное внимание уделено развитию зенитных комплексов ВМФ в СССР, Германии, США, Великобритании. Рассмотрены типы и характеристики ракетных комплексов, используемых на военных кораблях.

Ключевые слова: корабль, зенитные ракеты, война, «Катюша», вооружение.

го исследования, в котором бы рассматривались вопросы становления и специфики применения реактивного вооружения военно-морскими судами, основные направления, по которым происходило это развитие, факторы, его определяющие, и дальнейшие перспективы этого вида военной техники, в настоящее время отсутствует. Поэтому всестороннее и объективное изучение темы исследования будет способствовать углублению и актуализации научных знаний о развитии систем ракетного вооружения военно-морских флотов.

Достаточно наглядно и структурировано развитие реактивных систем залпового огня, а также особенности их применения вооруженными силами в период мировых войн на военно-морских судах демонстрирует эволюция средств вооруженной борьбы и способов ведения боевых действий, которая позволила автору выделить шесть поколений войн (см. табл. 1).

Как свидетельствует таблица 1, в войнах третьего поколения (приблизительно 200 лет назад) благодаря революции в военном деле впервые появились пороховые боевые ракеты. На вооружение флотов государств Европы и Северной Америки в это время пришли броненосный паровой флот, торпеды, стальная дальнобойная артиллерия. Первой скорострельной пушкой, принятой на вооружение Российского императорского флота (как 
Эволюция ведения боевых действий и средств вооруженной борьбы

\begin{tabular}{|l|l|l|l|l|l|l|}
\hline $\begin{array}{l}\text { Сравнивае-мый } \\
\text { параметр }\end{array}$ & $\begin{array}{l}\text { Война первого } \\
\text { поколения }\end{array}$ & $\begin{array}{l}\text { Война второго по- } \\
\text { коления }\end{array}$ & $\begin{array}{l}\text { Война третьего } \\
\text { поколения }\end{array}$ & $\begin{array}{l}\text { Война четвертого } \\
\text { поколения }\end{array}$ & $\begin{array}{l}\text { Война пятого по- } \\
\text { коления }\end{array}$ & $\begin{array}{l}\text { Война шестого } \\
\text { поколения }\end{array}$ \\
\hline $\begin{array}{l}\text { Основной вид } \\
\text { оружия }\end{array}$ & Холодное оружие & $\begin{array}{l}\text { Гладкоствольное } \\
\text { оружие }\end{array}$ & $\begin{array}{l}\text { Нарезное много- } \\
\text { зарядное оружие } \\
\text { повышенной } \\
\text { скорострельности, } \\
\text { точности и даль- } \\
\text { ности стрельбы }\end{array}$ & $\begin{array}{l}\text { Автоматическое } \\
\text { и реактивное } \\
\text { оружие, механизи- } \\
\text { рованные войска, } \\
\text { танки, авиация, } \\
\text { авианосцы, подво- } \\
\text { дные лодки }\end{array}$ & $\begin{array}{l}\text { Ракетно-ядерное } \\
\text { оружие }\end{array}$ & $\begin{array}{l}\text { Высокоточное } \\
\text { оружие, оружие на } \\
\text { новых физических } \\
\text { принципах, инфор- } \\
\text { мационное оружие, } \\
\text { силы и средства } \\
\text { радиоэлектронной } \\
\text { борьбы }\end{array}$ \\
\hline $\begin{array}{l}\text { Основной вид } \\
\text { противоборства на } \\
\text { море }\end{array}$ & $\begin{array}{l}\text { Абордажный бой } \\
\text { глерного флота в } \\
\text { прибрежной зоне }\end{array}$ & $\begin{array}{l}\text { Морские сражения } \\
\text { парусного флота в } \\
\text { прибрежных морях } \\
\text { поровых, металли- } \\
\text { ческих кораблей } \\
\text { различных классов }\end{array}$ & $\begin{array}{l}\text { Морские операции } \\
\text { Совместная воз- } \\
\text { душно-наземная } \\
\text { морская операция; } \\
\text { воздушно-косми- } \\
\text { ческая морская } \\
\text { операция }\end{array}$ \\
\hline
\end{tabular}

для кораблей, так и береговых батарей) стала 6-дюймовая (152-мм) пушка Кане. Использование поршневого затвора и унитарного патрона позволило достичь скорострельности до 5 выстрелов в минуту.

На протяжении войн четвертого поколения (около 100 лет назад) развитие реактивных систем залпового огня, которые начали активно применяться на вооружении судов и кораблей, осуществлялось, во-первых, путем снижения веса орудий, оптимизации размеров, увеличения дальности, кучности и скорострельности; во-вторых, путем создания орудий больших размеров, предназначенных для подавления долговременных укрепленных точек из стали, бетона и других устойчивых к поражающему действию материалов.

В Первой мировой войне значительно возросла роль подводных лодок и легких сил флота, оснащенных артиллерией. В период между Первой мировой войной и Великой отечественной войной отличительным качеством развития реактивной артиллерии стала ее универсализация, то есть применение одних и тех же орудий для стрельбы по наземным, воздушным и надводным целям.

Значительный прогресс в развитии реактивных систем залпового огня для военно-морских судов в период мировых войн удалось достигнуть Великобритании, Германии, Советскому Союзу и Соединенным Штатам.

Развитие реактивных систем залпового огня на Британском военно-морском флоте начиналось с внедрения комплекса UP Mark I, который был одним из видов стрелкового ракетного оружия, предназначенного для ближнего действия. Он нашел свое активное применение на многих крупных британских военных кораблях в начале
Второй мировой войны. Каждая установка представляла собой набор из двадцати гладкоствольных трубок, обычно выстреливаемых по десять штук за раз [1].

В дальнейшем для усовершенствования работы установки были адаптированы ракеты I-Go IA и I-go IB. I-go IA имела длину 18,9 фута и размах крыльев 11,8 фута. Ракета весила около 3085 фунтов и имела максимальную дальность полета в семь миль при максимальной скорости 340 миль в час. I-go IB была длиной 13,4 фута с размахом крыльев 8,5 футов. Ракета весила около 1500 фунтов и имела максимальную дальность полета в пять миль при максимальной скорости 340 миль в час.

Также на флоте нашла свое применение установка RP-3, которая была оснащена снарядами со стабилизацией вращения диаметром 3 дюйма, длиной 5,35 фута. Каждый снаряд весил около 60 фунтов, его максимальная скорость была 1000 миль в час и максимальный диапазон в одну милю. Ракеты RP-3 обычно запускались парами по направлению к целям на земле.

Военно-морской флот США с 1940 года запустил в производство мощные ракеты диаметром 7,2 дюйма, которые предназначались для стрельбы по бункерам и наземным укреплениям. ВМФ для их запуска использовал 24-трубнную пусковую установку под названием «Grand Slam». Кроме того, военно-морской флот также оснащал десантные корабли пусковой установкой из 120 труб под названием «Woofus». Отдельное внимание необходимо обратить на тот факт, американские корабли использовали ракету, которая несла противолодочную бомбу. Комбинации ракета/бомба были известны как «мышеловки» и обычно запускались с корабля в направлении расположенной подводной лодки [2]. 
В Германии, начиная с марта 1940 года, в производство был запущен ракетно-зенитный комплекс под названием $15 \mathrm{~cm}$ Nebelwerfer (Небельверфер) 41 (Nb.Wrf. 41), который стал самым знаменитым и массовым оружием вермахта. Он использовался для стрельбы газовыми минами или для постановки дымовых завес. С 1941 года данный комплекс начали устанавливать на немецкой подводной лодке U-511. После успешного применения Nb.Wrf.41 были разработаны и поступили на вооружение другие, более мощные комплексы ракет калибров от 210 до 320 мм и пусковых установок 28/32 cm Nb.Wrf.42; 21 cm Nb.Wrf.42; 30cm R.Wrf.56; S.WG40 и другие [3].

В Советском Союзе архивные материалы свидетельствуют о том, что еще до войны на флоте испытывались реактивные осветительные снаряды и безоткатные реактивные пушки типа «ДРП». После начала Великой отечественной войны на катерах Черноморского флота «малый охотник» МО-2 впервые было установлено ракетно-пусковое четырехзарядное устройство для запуска неуправляемых авиационных ракет PC-82. После успешного апробирования данного оружия на флоте, советские корабли оснащались установкой М-13-MI надпалубного типа, М-8-М башенно-палубного типа. А с 1942 года для кораблей специально адаптировалась зенитная установка «Катюша», получившая конфигурацию 24-М-8 (24 реактивных снаряда), 16-М-13 (16 снарядов).

Таким образом, в статье рассмотрены направления развития реактивных систем залпового огня и особенности их применения вооруженными силами в период мировых войн на военно-морских судах СССР, США, Германии и Великобритании.

\section{ЛИТЕРАТУРА}

1. Erik Bergaust Rockets of the Navy. New York: G. P. Putnam's Sons, 1959. 48 p.

2. The U.S. Navy's «Interim» LSM(R)s in World War Il: rocket ships of the Pacific Amphibious Forces / Ron Mackay, Jr. Jefferson, North Carolina: McFarland \& Company, Inc., Publishers, 2016. $244 \mathrm{p}$.

3. Hitler's naval bases: Kriegsmarine bases during the Second World War / Jak P. Mallmann Showell. Stroud: Fonthill, 2013. 255 p.

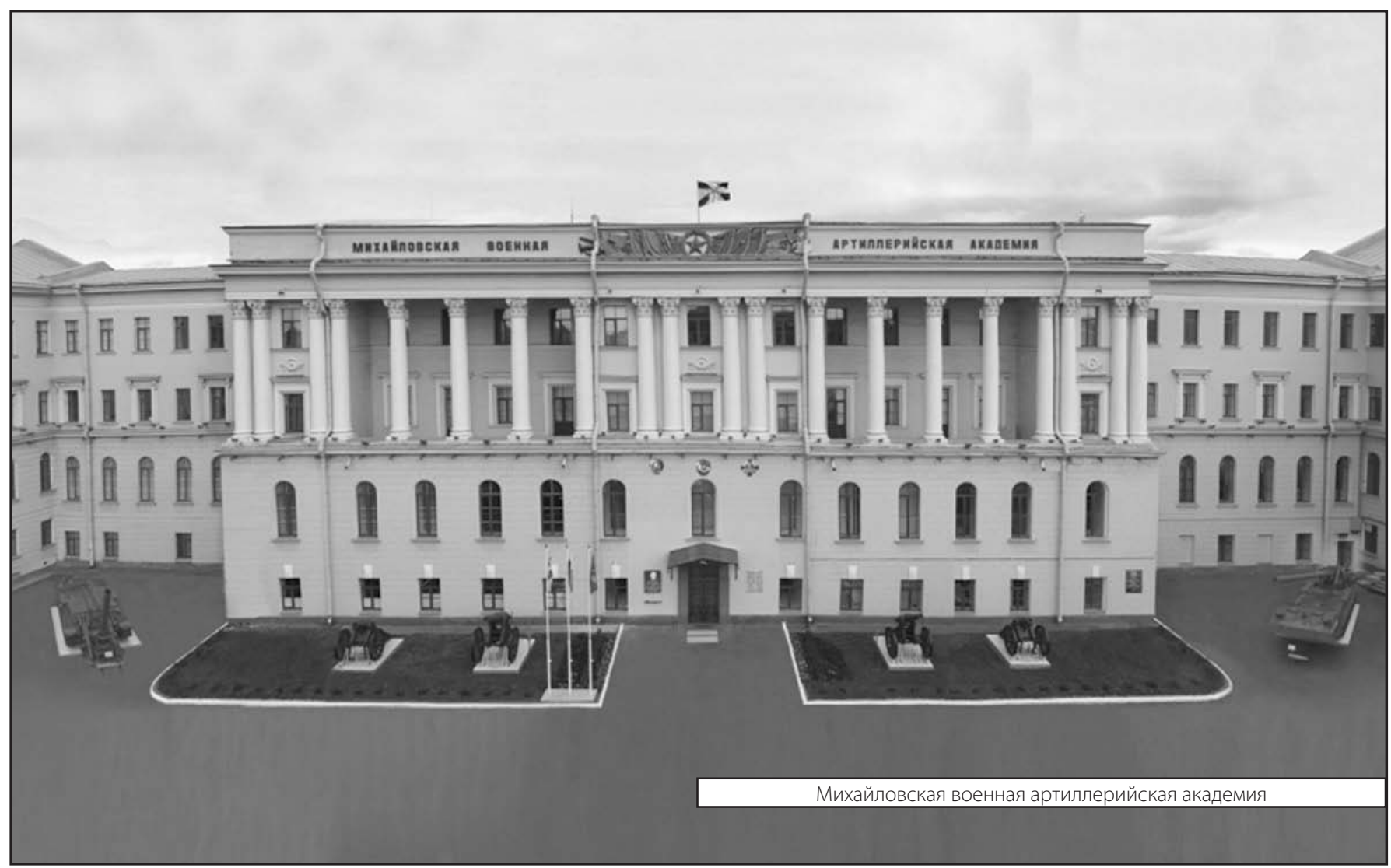

